\title{
Analysis of Ways to Enhance Fujian's Foreign Trade Competitiveness
}

\author{
Dai Siwei \\ Economics and Trade Department, Fuzhou University of International Studies and Trade \\ Fuzhou, Fujian 350202
}

\begin{abstract}
This paper analyzes the current situation of foreign trade in Fujian Province from different perspectives on the international market share of Fujian's foreign trade and the index of trade competitiveness, etc., and further analyzes the shortcomings of Fujian's foreign trade competitiveness and the future development trend of foreign trade. The way to further develop the international competitiveness of Fujian's foreign trade is put forward.
\end{abstract}

Keywords-Competitiveness; Trade competitiveness index; Foreign trade; International market share

\section{INTRODUCTION}

Since the beginning of the new century, Fujian's foreign culture, economy and trade have been developing rapidly, and the trade economy accounts for a large proportion of Fujian's development. Fujian's value of exports increased from 12.90828 billion dollars in 2000 to 112.68011 billion dollars in 2015 , with an average annual growth rate of $15.54 \%$. The foreign trade export scale of Fujian Province takes the seventh position in the country for a long time. Compared with other provinces in China, the grade and added value of Fujian Province's export products are still relatively weak, and the competitiveness of Fujian Province's foreign trade has a lot of space to improve. Fujian Province is one of the first two provinces opening to the outside world. Its degree of economic export-oriented is very high and the degree of dependence on foreign trade has been above $40 \%$. Therefore, it is of great significance to improve the international competitiveness of Fujian Province's foreign trade.

\section{ANALYSIS ON THE CURRENT SitUATION OF FUJIAN'S FOREIGN TRADE COMPETITIVENESS}

The competitiveness of foreign trade is divided by taking export trade as the standard. For some trade systems, the competitiveness of foreign trade is the means of competition in the export trade. "Foreign trade competitiveness is the ability of a country or region to express international division of labor and international competition by trade activities and the ability to expand market share in the international market to achieve economic development. Therefore, the competitiveness of foreign trade is an important form of expression of international competitiveness".

2017 special topic of China Association of International Trade

(2017MYXHZX004).

\section{A. Analysis of the International Market Share}

From 2000 to 2015, China's export volume increased from 249.2 billion dollars to 2280 billion dollars, and China's share in the international market rose from $3.860 \%$ to $13.835 \%$, with a steady increase in the trend, Fujian's value of exports rose from 12.90828 billion dollars to 112.68011 billion dollars in the same period, and the share of Fujian in the international market increased from $0.1999 \%$ to $0.6837 \%$, the trend is a steady increase; while Fujian's share of China's exports has been $5.1799 \%$ to $4.9421 \%$, there have been some changes during the period, but in general, these changes are small Therefore, the international competitiveness of Fujian's foreign trade has been increasing in the past 15 years, but compared with the international competitiveness of other coastal provinces, the speed of development is not outstanding. For example, the value of exports of Zhejiang Province which is a coastal province as well, has increased from 19.44279 billion dollars to 276.33211 billion dollars in the same period, and Jiangsu Province's value of exports has risen from 25.76979 billion dollars to 333.65671 billion dollars in the same period, and Guangdong Province's value of exports has increased from 91.91954 billion dollars to 379.32769 billion dollars [1].

\section{B. Analysis of the Trade Competitiveness Index}

The trade competitiveness index, namely TC index, "Represents the proportion of the difference between the import and export trade of a country or region in total value of import and export trade". TC index = (value of exports- value of imports) / (value of exports + value of imports). This paper calculates the trade competitiveness index of the ten categories of trade products in Fujian Province from 2010 to 2015.

From 2010 to 2015, Fujian Province's trade products with stronger trade competitiveness (TC index >0) has four categories: (SITC0) food and live animals, (SITC6) manufactured products classified according to raw materials, (SITC7) machinery and transport equipment, and (SITC8) miscellaneous products. Among them, the trade competitiveness index of (SITC8) miscellaneous products and (SITC6) manufactured products classified according to raw materials is the strongest, and has a trend of increasing year by year; although the competitiveness of (SITC7) machinery and transport equipment is not very strong, it still has a trend of increasing year by year; the trade competitiveness of (SITC0) food and live animals has started decreasing year by year since 2011. 
The six categories of trade products with weak trade competitiveness (TC index <0) include (SITC1) beverage and tobacco, (SITC2) inedible raw materials, (SITC3) mineral fuel, lubricating oil and related raw materials, (SITC4) animal and vegetable oil, fat and wax, (SITC5) chemical products and related products, (SITC9) unclassified products. Among them, the trade competitiveness of (SITC1) beverage and tobacco, (SITC3) mineral fuel, lubricating oil and related raw materials became weaker year by year; the trade competitiveness of (SITC4) animal and vegetable oil, fat and wax, (SITC5) chemical products and related products has a tend to become stronger; (SITC2) the trade competitiveness of (SITC2) inedible raw materials has not changed much. [2]

From the view of export commodity structure, the trade competitiveness of primary products in Fujian Province has been in a weak state, gradually decreasing from 2010 to 2014, but rising again to TC index $=-0.43$ in 2015 . The industrial products in Fujian Province have been in a strong state and have a trend of increasing year by year, rising to $\mathrm{TC}=0.51$ in 2015. This shows that the structure of Fujian Province's export commodities is being optimized year by year, and the export of industrial products is increasing year by year [3].

\section{MANIFESTATION OF FUJIAN'S INSUFFICIENT FOREIGN TRADE COMPETITIVENESS}

\section{A. Competitiveness of Traditional Industries is Deficient and the Bargaining Power of Enterprises is Poor.}

Fujian Province's value of exports in garment industry accounts for a large proportion of total exports of Fujian Province. But its export competitive advantage is weaker, because the added value of product exports is relatively low, and the price growth is very limited. It has been found after deep exploration that the real reason lies in the large number of small subjects in the traditional industry in Fujian Province, resulting in the poor bargaining power of the enterprises, and even the vicious competition between the enterprises in the province. At present, the main problems which the traditional industry of Fujian is facing lies in the relative concentration of export market, the low concentration of enterprises and the confusion of the market caused by over vicious competition, resulting in the low profit rate of the traditional industry. With the increasing of the RMB exchange rate and the rising of the labor price, the export promotion of the traditional industry will be subject to the great challenge.

\section{B. Enterprise is Lack of Innovation Consciousness}

In Fujian, most of the foreign trade enterprises are private enterprises, which are not valued for the future development of enterprises, and they are mainly concerned with current interests. Therefore, these private enterprises are not willing to invest in the promotion of production technology and the innovation of marketing mode, etc.. They prefer to put the funds into the industries which can bring benefits and have high rate of return in a short term. The lack of funds leads to a great restriction on the development of the traditional industry in Fujian Province. In addition, the leaders of these enterprises are basically relying on themselves to fight, from small to large, and they do not have systematic and scientific management mode and are not initiative in the aspect of innovation.

Even if enterprises are innovating in some technology, our protection sense for intellectual property rights is not strong enough, and the other enterprises are competing to imitate, which causes these innovative enterprises not to dare to innovate.

\section{Export Products are Concentrated and Labor-intensive Products Account for a Larger Proportion.}

The types of export products in Fujian Province are few and relatively concentrated. Textile, food, hardware and light industry are the main categories of Fujian Province's export products. Moreover, processing trade is dominant and independent brands are few. The low added value of products makes Fujian Province less competitive in the process of export, and the price of products is the main competitive means of Fujian Province's export products. As a result, trade frictions occur frequently in several major industries, and anti-dumping is always suffered in textile, light industry, hardware, mechanical and electrical, food and other several major pillar industries, especially in textile, clothing, footwear and other product fields.

\section{WAY TO ENHANCE THE INTERNATIONAL COMPETITIVENESS OF FUJIAN'S FOREIGN TRADE}

\section{A. Be Alert to the Comprehensive Cost of Production and Improve the Competitive Advantages of Traditional International Trade.}

At present, the world economy is recovering slowly, the international trade situation is still very severe, the world economy is still under the background of deep adjustment, the number of uncertainties in the development of international trade is increasing, and some unstable factors cannot be corrected, resulting in the stability of the sustainable development of trade becoming worse and worse. We should be alert to the rising of comprehensive production cost and the risk of weakening competitive advantage of traditional international trade. So I should:

Firstly, pay attention to the changes in the political and economic situation of the two major trading partners of the United States and ASEAN, and prepare for the changes in international trade brought about by policy changes in advance.

Secondly, the government should actively assist enterprises in coping with restrictive measures for trade and minimize the interference of trade friction on the development of Fujian Province's foreign trade.

\section{B. Increase Investment in Science and Technology and Promote Technological Innovation and Development.}

Commodity price has always been the main factor in international competition, but the lagging foreign trade export mode that still relies on "winning by quantity and winning by price" will be eliminated by the changing international market. At the moment when the international economy is relatively low and the country needs to stabilize the export of 
commodities, in order to promote the vigorous development of Fujian's foreign trade, the quality of commodities should be promoted while ensuring the steady progress of the quantity of export commodities. We should increase investment in science and technology and introduce new and high technology, so as to enhance the added value of export products and make export products in a higher level and grade in the international market. The government can encourage enterprises to enhance the investment in research and development, and low interest loans and even interest free loans can be given to enterprises that strengthen technology research and development. We should establish a better incentive mechanism for innovation so as to promote enterprises' continuous innovation. Enterprises that make outstanding contributions to scientific and technological research and development and innovation can be given a certain degree of tax reduction and exemption policy. The investment of enterprises in research and development is enhanced, and the innovation system of science and technology is perfected day by day. At the same time, the brand development strategy can be implemented, the independent brand is cultivated and the brand competitiveness can be promoted [4].

\section{Improve the Level of Processing Trade and Vigorously Develop General Trade and other Modes of Trade.}

We should improve the level of processing trade, encourage enterprises to actively carry out technological transformation, increase the export proportion of high technology content and high value-added products, improve the quality, grade and level of traditional export commodities, vigorously cultivate and support the export of independent famous brand products while developing processing trade, and realize the transfer of processing trade products from labor intensive products to technology and capital intensive products, and intensify the development of general trade and other modes of trade [5].

\section{Speed up the Adjustment of Industrial Structure and Enhance the Competitiveness of Export Products.}

The types and simplicity of export products are the main causes that Fujian Province's foreign trade is lack of international market competitiveness, and the type of export product is simple and relatively lack of the risk tolerance capability of foreign trade. Therefore, to accelerate the import and export industrial structure adjustment of Fujian Province and improve the competitiveness of export products is one of the important measures to promote the rapid development of import and export trade and foreign trade in Fujian Province.

First of all, we should appropriately lower the target of the quantity of export products, raise the target of the quality of export products, get rid of the past "winning by quantity ", and advocate "winning by quality". We should change the export product structure, realize the change from the export processing trade to the export of the independent product, encourage the transfer from labor intensive industry to the technology intensive industry, improve the quality of the product, the technical content, the process improvement and the added value of the product, and help the small and medium enterprises to improve the international market competitiveness of their products.
Secondly, we should strengthen the scientific research and development of enterprises themselves, strive to innovate, vigorously develop strategic emerging industries, develop industries with Chinese characteristics, and attract foreign capital investment.

Finally, as the main operation mode of export trade, enterprises should actively enhance the investment and innovation, carry out the humanity culture and science technology innovation and develop unique independent brands. According to the changes in the international and domestic markets, the operators should choose the development projects independently, take their own risks and assume sole responsibility for their profits or losses, and the state vigorously supports the operation mode transformation, enterprises should build research and development centers and optimize the allocation of technological resources [6].

\section{SUMMARY}

In a word, Fujian Province's foreign trade is showing a continuous optimization situation. In this period, we should improve the quality and added value of foreign trade commodities in Fujian province, appropriately lower the target of the quantity of export products, improve the target of the quality of export products, get rid of the past "winning by quantity", and advocate "winning by quality". Enterprises can increase the investment in scientific research and carry out scientific and technological innovation faster, and can implement brand development strategy, cultivate independent brand and improve brand competitiveness at the same time, and can also buy and merge some foreign brands, so as to reduce the time of independent brand creation, and also reduce the risk of independent brand creation. The government can give better policies and better environment to foreign trade, so as to promote the better development of Fujian's foreign trade. Meanwhile, we should also broaden the development space of foreign trade in Fujian Province. We should not rely solely on the traditional market and the Southeast Asian market. We should expand the scope of trade, open up new trade fields, and strengthen economic exchanges and contacts with other countries, thus further promoting the further vigorous development of Fujian Province's foreign trade.

\section{ACKNOWLEDGMENT}

"Supported by the Training Program of Fujian Excellent Talents in University" in English, and "FETU" for short); Chinese International Trade Association Topic in 2017 (2017MYXHZX004)

\section{REFERENCES}

[1] Lin Daoyu. Research on the Transformation of Fujian's Foreign Trade Growth Mode [J]. Commercial Times, 2012, (21): 52-53.

[2] Chen Chunling. Strategy of Supply Chain Management in the Development of Fujian's Foreign Trade. Journal of Jimei University [J], 2014, (1): 26-33+39.

[3] Zhang Ni. Rules must be fairer If Free Trade is hoped to be More Inclusive. [N]. China Economic Times, 2015-03-22 (6).

[4] Yang Yuanjie. Review of World Economic Situation in 2016 and outlook for 2017 [J]. China State Finance, 2017, (4): 64-65

[5] Huang Yi. Analysis of the Competitiveness of Sichuan's Service Trade [J]. Journal of International Trade, 2012, (1): 126-127

[6] Fu Qiang. Analysis of the competitiveness of Sichuan's service trade [J]. Journal of Southwest University for Nationalities (Natural Science EDITION), 2012, (7): 678-682. 